\title{
An African American perspective on the New Testament COMMENTARY
}

Book Title:

True to our native land:

An African American

New Testament

Commentary

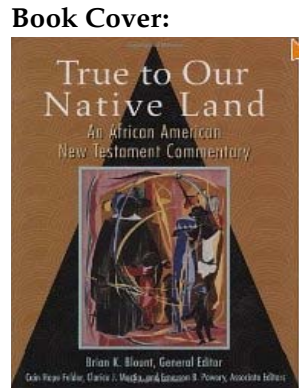

Author:

Brian K. Blount

ISBN:

978-0-8006-3421-6

Publisher:

Fortress, Mineapolis, 2008, pp. $565, \$ 30.00^{*}$

*Price at time of Review

\section{Review Title:}

An African American

perspective on the

New Testament

Reviewer:

Ignatius (Natie) W. C. van Wyk $^{1,2}$

\section{Affiliation:}

${ }^{1}$ Africa Institute for

Missiology, Pretoria,

South Africa

${ }^{2}$ Reformed Theological

College, University of

Pretoria, South Africa

email:

aim1@mweb.co.za

Postal address:

The Africa Institute for

Missiology, PO Box 32186,

Waverley 0136, South

Africa

How to cite this book review:

Van Wyk, I.W.C., 2010,

An African American

perspective on the New

Testament', HTS Teologiese

Studies/Theological Studies

66(1), Art. \#982, 1 page.

DOI: 10.4102/hts.v66i1.982

This review is available

at:

http://www.hts.org.za

(c) 2010. The Authors.

Licensee: OpenJournals

Publishing. This work

is licensed under the

Creative Commons

Attribution License.
This New Testament commentary is the product of African American theologians. A variety of scholars have produced explanations of every book of the New Testament, with explanations varying in length of 20-30 pages. Short comments or explanations are offered on every pericope of the New Testament. Amongst the authors are Brian Blount (editor), president of the Union Theological Seminary, Richmond; Cain Felder, professor of New Testament, Howard University, Washington; Clarice Martin, professor of Philosophy of Religion, Colgate University and Emerson Powery, professor of New Testament, Lee University, Cleveland.

The Commentary is filled with longer and shorter quotations from African and African American writers, past and present. These quotations come in the form of poems, paragraphs from novels and academic writings. The majority of these quotations capture the emotions of people who were forced into slavery, the hardships of their families and descendents and the bitterness and intellectual struggles of present-day African Americans. It is therefore an emotional commentary - a commentary filled with anger, born out of the experience of slavery.

Undoubtedly, this commentary will receive its share of criticism and sarcasm. Purists will reject it as an exercise in contextualisation which fails the test of scientific excellence and exegetical objectivity. One should, however, look at the aim of the commentary, namely to interpret and understand the New Testament from the experience of slavery, an aim that in my opinion is justifiable. Slavery is one of the scandals of humankind. Tribes, even whole nations were destroyed through slavery. The fact that churches participated in the horror must have saddened our Lord. We should therefore all be sensitised that Christians, at least, would never again take part in such activities.

Slavery is still happening in the world today. This commentary will certainly help the church today to realise its prophetic duty. One cannot help but look at this commentary with different eyes after having seen the pictures, paintings and sketches of people who had been lynched, tortured and murdered by their masters. One cannot help but acknowledge the necessity for a publication such as this.

Another worthy attribute of this book is the good introductory articles on the following topics:

- slavery in the Early Church

- the place and role of Africa and African imagery

- Paul and African American biblical interpretation

- 'we will make our own future text': an alternate orientation to interpretation

- womanist biblical interpretation

- African American preaching and the Bible

- African American art and biblical interpretation.

In spite of all the commendations this commentary deserves, its weaknesses cannot be overlooked. To force almost every single text verse in the New Testament into one single frame of reference, namely slavery, is theologically irresponsible. Such exegetical methodology shows no respect for the variety and depth of the New Testament. The consequence of the hermeneutical key of the commentary is that it must work with a canon within the canon. As readers would expect, the book of Philemon poses serious problems. The following quotations would illustrate the point:

... Philemon ... is highly problematic for African Americans ... We wish that Paul would say of Onesimus, once he was a slave, but now he is emancipated. He says no such thing overtly.

As well as:

Enslaved African Americans and subsequent generations appropriated [the notion of the equality of humanity] as a revolutionary hermeneutic for understanding Scripture. This African American hermeneutic was based on their existential reality; even if the Scripture said, 'slaves obey your masters', it could not be the word of God because it justified the suffering of human beings ...

(pp. 437-438)

In spite of its negative points, I would still recommend this book to all. Everyone who has respect for human life should read it - it could be a life-changing experience. 